\title{
The Effect of Edutainment Learning Model on Early Childhood Socio-emotional Development
}

\author{
Khadijah $^{1}$ \\ Arlina $^{2}$ \\ Miftahul Jannah Addaudy ${ }^{3}$ \\ Maisarah $^{4}$ \\ Universitas Islam Negeri Sumatera Utara, Indonesia ${ }^{1,2,3,4}$
}

DOI: https://doi.org/10.21009/JPUD.152.01

Accepted: September $15^{\text {th }}$ 2021.Approved: October $4^{\text {th }} 2021$. Published: November $30^{\text {th }}, 2021$

\begin{abstract}
The idea of edutainment began to become the interest of early childhood educators to make the learning process more holistic, including knowledge about how the brain works, memory, motivation, self-image, emotions, learning styles, and other learning strategies. This study aims to analyse and compare the effect of edutainment and group learning on the socio-emotional development of early childhood. This research method uses a quasi-experimental design with data collection techniques derived from the results of the pre-test and post-test on 20 children. The results of this study indicate that there are differences in the influence of edutainment learning with the control group on the social-emotional development of early childhood. Although both groups affect the socioemotional development, edutainment learning has a better effect than the control group. For further research, it is recommended to create various types of edutainments learning to improve various aspects of children development.
\end{abstract}

Keywords: Early Childhood, Edutainment Learning Model, Socio-emotional Development

\footnotetext{
${ }^{1}$ Corresponding Author:

Universitas Islam Negeri Sumatera Utara

Email: khadijah@uinsu.ac.id
} 


\section{INTRODUCTION}

Socio-emotional development is related to feelings /qalb (Nasser et al., 2019). The word Qalb is often found in the Qur'an and Hadith. The heart occupies an important position in achieving the meaning of life and life both now and in the future. In the Qur'an it has been explained about feelings of pleasure in Surah QS. Ali Imran: 14. The interpretation of this verse talks about all that is used as jewellery for humans in life in this world, in the form of various pleasures, which include women and children. Educators, parents, and governments are increasingly realizing the importance of socioemotional development. Children can acquire skills and acquire information through social-emotional competence and achieve well-being and exercise resilience. In fact, critical developmental milestones early in life are aided by social-emotional skills (Chung et al., 2020). Various adjustment indicators, including prosocial behaviour, selfregulation, school preparation, and academic performance, were also predicted by socioemotional ability (Ren et al., 2016).

Children continue to develop social and emotional skills. They gain the confidence and competence needed to build relationships across settings, solve problems, and cope with challenges. Therefore, socio-emotional is one of the five aspects of development that is important to be developed in children as early as possible to form children who have character and are ready to attend higher formal education (Halle \& Darling-Churchill, 2016). Early childhood educators regard social and emotional skills and drive as more essential than being able to read in kindergarten, according to studies. Furthermore, they see the interaction between instructors and young children as a good aspect in the development of children's self-awareness and a key feature in their social-emotional development (Heller et al., 2012).

Educators and parents of young children are taught to think that edutainment helps their children improve their talents or development aspect, such as social-emotional (Okan, 2003). Since the goal of edutainment is the enjoyable learning of one or more abilities in a particular developmental area, it is promoted as a valuable experience for children. The concept that learning is "fun" underlies edutainment learning. Researchers commonly refer to these games as edutainment since they impart instructional information using game-like structures, visual aids, and a slightly didactic approach (Okan, 2003). Edutainment games provide basic play that targets certain abilities for young children (e.g., counting, sorting, letter identification). However, because few edutainment games are assessed or reviewed for educational advantages or children's learning, the true educational benefits are mostly unknown (Hirsh-Pasek et al., 2015).

Edutainment is a learning model that can create feelings of pleasure in children and create a conducive learning atmosphere. The fun learning process is eagerly awaited by children and creates motivation for children to learn every day. Edutainment not only affects learning activities but also provides better learning outcomes. Several researchers have highlighted the importance of play in managing emotions and promoting children's resilience in the face of adversity (Capurso \& Ragni, 2016; Marcelo \& Yates, 2014). 
However, there is no research that analyses the effect of the edutainment learning model on the socio-emotional development of early childhood.

The results of observations at Raudathul Athfal (RA) ABATASA Yapuspenda Medan showed preliminary observation data that 11 out of 20 students (55\%) had underdeveloped social and emotional aspects, and 9 out of 20 students (45\%) developed. This is characterized by many children who are not enthusiastic, are not polite in talking to their peers or with their teachers, do not intervene with friends who are fighting, and compares friends with each other. Attitudes or behaviour of children found at the time of observation reflects the low socio-emotional aspects of children, and this is the impact of the lack of good guidance from adults around children, including guidance at school.

This research analyses the influence of the edutainment learning model and the group learning model on children's socio-emotional development and it important to do because socio-emotional is the foundation for children to have mental readiness and social interaction skills. Special Attention needs to be paid if there are problems of low children's socio-emotional development, such as the findings of initial observations at RA ABATASA Yapuspenda Medan. With the application of the edutainment learning model in this study, it is not only to influence the socio-emotional development of children, but also to provide an example to the teacher who learning should use game tools or play activities that are in accordance with the child's developmental stage. In addition, the application of playing activities or the use of game tools in the edutainment learning model will create a sense of pleasure. In this, study also applied the group learning model because this model is often used in schools but has a good impact on children's social and emotional. This Research was conducted with the aim of knowing the differences in the effect of edutainment learning and group learning models on the socio-emotional development of early childhood.

\section{THEORITICAL STUDY}

\subsection{Socio-emotional Development}

The development of social-emotional begins in early infancy when children form interactions with peers and adults. This natural need leads to awareness of one's own emotional state, recognition of other people's emotions while reading situational and expressive signals and having empathy for them, knowledge of terms related to feelings and how to use them, and the ability to distinguish internal and external, positive, and negative emotions, cope with them, and express them in communicative behavior (Protassova, 2021).

Social-emotional development is defined as the acquisition of values, knowledge, and abilities that enable children to connect effectively to others and contribute positively to their families, schools, and communities. Emotional awareness and comprehension are essential for this. Emotional knowledge entails the ability to detect and control powerful emotions to sustain healthy interpersonal interactions. Individuals with emotional 
comprehension can appropriately perceive and respond to the emotional cues of others (Sprung et al., 2015). Children may gain socially and intellectually from emotional training, according to Sprung et al., (2015) especially if the training is given over time.

The term social-emotional competence refers to a child's ability to interact socially, and it encompass social, emotional, and social-cognitive abilities and behaviors (RoseKrasnor, 1997). Denham, (2006) defined five categories of social-emotional competence, such as emotional expressiveness, emotion understanding/knowledge, emotion and behavior management, social problem solving, and social and relationship skills in one well-known framework. Social-emotional skills are a crucial part of school preparedness. Social-emotional development refers to a child's increasing ability to feel, control, and express emotions, build intimate and secure interpersonal connections, and explore the world; and learn. McClelland and Cameron (2011) have connected social-emotional competence to kindergarten achievement, primary school performance, and even adult accomplishments.

Children nowadays are emotionally immature, which presents a dilemma. These days, a child's greatest companions are digital devices and television, and their favorite methods to pass the time include watching animated movies and playing computer games. In the future, the increased screen usage may result in little to no communication with adults and peers. When it comes to preschoolers' leisure activities, keep in mind that at a young age, youngsters might become insensitive and unable of managing their own emotions (Watanabe et al., 2019). Various extrinsic influences, such as family relationships, teacher behavior, and the country in which they live, have an impact on the socio-emotional development of preschoolers and their personal qualities (Breaux et al., 2016). According to recent research, children who do not live with both parents have greater challenges than children who live in the entire household. Furthermore, when stratified by custody arrangements, females living alternately with each parent in rural areas experience greater problems than in urban areas (Eurenius et al., 2019).

One of the most pressing issues in personality development is getting children to understand social standards. The accumulation of social experience by a youngster on his or her own time and under the supervision of adults adds to the development of potential. It also provides for the development of school ready skills as well as the life skills required to deal with adulthood. As a result, the preschool years are a time when the foundations for a child's social maturity (competence) are being laid (Garner \& Parker, 2018). This sets the stage for his or her development and makes adaption attempts easier. The child's social development is a complicated process in which he or she adapts to objectively established behavioral standards and continually discovers oneself as a social subject (Alwaely et al., 2021).

Afrianti (2018) suggests that the socio-emotional competencies of children aged 5-6 years are: (1) be cooperative with friends, (2) showing tolerance, (3) and expressing emotions in accordance with the existing conditions. (4) Know manners in accordance with local socio-cultural values, (5) Understand the rules and discipline, (6) and show 
empathy. (7) Have a persistent attitude (not give up easily), (8) Proud of their own work, and (9) Appreciating the advantages of others. The five indicators of early childhood socio-emotional development, they are broken down into ten achievement indicators. Children willing to play with friends, share with friends, helping friends, not comparing friends with each other, happy when getting something, enthusiastic when doing the activities, they want to speak politely, obey the rules of the game, comfort a sad friend, and break up a fighting friend.

The socio-emotional development of children in this study was carried out by applying edutainment and group learning models. (Shodiqin, 2016)concluded in his research that edutainment-based learning is always dynamic and develops in accordance with the development of information and communication technology. Edutainment is one of the lessons that creates an interesting and fun impression for students. Rusydi (2018) found that edutainment learning steps focus on entertainment, establishing harmonious communication between teachers and students, and increasing positive emotions in children regarding learning motivation. The application of edutainment learning strategies that combine education and entertainment systems in education can provide an educational process that can be very interesting and entertaining for students. Teachers and students feel happy, comfortable, do not cause boredom in learning activities in the classroom to achieve the learning objectives set. The educational process with an edutainment approach through games, humor, role play, and demonstrations and other ways that can be mastered by teachers and students (Andri Oza \& Zaman, 2016; Purwanto, 2019). By applying the edutainment learning model, early childhood does not feel bored or even does not feel that they are studying strictly, because they learn in a fun way but still have meaning.

Munirah (2018) reveals that there are several urgencies that underlie the need for children's socio-emotional development from an early age, including: children need awareness and understanding of the problems around them. Children must have stable emotions, and the social and emotional possessions of children affect interpersonal intelligence. Nurmalitasari (2015) argue the relationship between social and emotional development tends to encourage one's social activities. A person's emotions are determined by the existence of social competence. Someone with high emotional intelligence tends to be a socially competent person. Thus, socio-emotional in children is very important to be developed as optimally as possible.

\subsection{Edutainment Learning Model}

The term "edutainment" is derived from the word's "education" and "entertainment." Edutainment is derived from the word's education and entertainment. Edutainment is a learning process created in such a manner that the substance of education and entertainment may be merged in harmony so that learning is more pleasant, pleasurable learning is generally done using comedy or games, role play, and demonstration in terms of edutainment terminology. Classroom resources, films, and activities that are both informative and pleasurable are referred to as edutainment (Pojani \& Rocco, 2020). 
The major purpose of "edutainment" is to assist diversify the process of acquiring information via entertainment. Theory is combined educational goals and means, life values, and it allows for "present experience and amusement through creativity." It's worth mentioning, however, that "edutainment" covers a tiny part of the educational process, it only helps to diversify learning without demanding a change in the standard learning paradigm (Chilingaryan \& Zvereva, 2020). It may be considered that edutainment is frequently employed in the learning process in general since one of its distinguishing aspects is the simultaneous learning and gratification of one's curiosity. The gratification of one's curiosity, continuous interest, on the other hand, is nothing more than a pastime. As a result, edutainment may be thought as a sort of training, but not in the limited sense of amusement, but rather as main enjoyment that leads to continue, profound interest.

Some concepts are common to edutainment techniques, such as the notion of edutainment, which is a set of learning methodologies that aims to bridge the gap between the teaching and learning processes. The edutainment idea aims to make the learning process more holistic, including knowledge of how the brain works, memory, motivation, self-image, emotions, learning styles, and other learning strategies. The primary notion of edutainment is to make learning possible in a pleasant and enjoyable environment. There are three assumptions to be based on: a) pleasant sentiments, b) developing positive kid emotions, and c) maximizing the capacity of children's reasoning properly and able to double their learning accomplishments. Children who are adequately educated, motivated, and taught in the correct method (one that recognizes the child's style and desires) will attain optimal learning results.

It is critical to understand the skills and limitations of preschoolers to build sensible edutainment for them. For various age groups, in-depth knowledge of children's development is required. There are rules and recommendations for creating interaction for children, but the age group they are referring to be rather broad, ranging from zero to eight years (Crescenzi-Lanna \& Grané-Oró, 2016). Because there are significant disparities among children in this age range, it is necessary to get to know and understand the children who will use an application.

\section{METHOD}

This study uses a quantitative approach with a quasi-experimental design (nonequivalent control group design) (Creswell, 2015). The first group is the experimental group by applying the treatment of the edutainment learning model, and the control group is given the treatment of the group learning model. Observations in each sample group were carried out twice, before (pre-test) and after treatment (post-test).

\subsection{Participant}

The participant in this study consisted of 32 PAUD children at RA ABATASA Yapuspenda Medan, which were divided into three classes, namely: 12 children aged 4- 
5 years in class A, 10 people in class B1 and 10 people in class B2. This study using purposive sampling technique with consideration, first requires two classes or groups of children, both children must have the same age range. Based on these considerations, the sample in this study was 20 PAUD children divided into two classes, 10 people in class B1 applied the edutainment learning model (experimental group), 10 people in class B2 applied the group learning model (control group).

\subsection{Experiment Design}

The Non-Equivalent Groups Design (hereinafter referred to as NEGD) is perhaps the most frequently used design in social research. The researcher selects two comparable groups and tries to choose the group that is as similar as possible so that the researcher can fairly compare the treated with the compared, although the researcher can never be sure, the groups are comparable, therefore, homogeneity test was carried out in this study. This quasi-experimental design can be seen in table 1 .

Table 1. Non-equivalent Control Group Design

\begin{tabular}{cccc}
\hline Group & Pretest & Treatment & Postest \\
\hline Experiment & $\mathrm{O}$ & Edutainment Learning Model & $\mathrm{O}$ \\
Control & $\mathrm{O}$ & Group Learning Model & $\mathrm{O}$ \\
\hline
\end{tabular}

\subsection{Instrument}

The form of the instrument is a teacher's observation sheet with an assessment rubric so that the teacher or researcher can use it appropriately. The accuracy and reliability of the instrument were also analyzed using three types of validity (content, construct, and empirical) and reliability analysis using Cronbach's alpha formula. Content validity is done by analyzing observation sheets based on the achievement of indicators from various theories (see Table 2).

Table 2. Socio-emotional Development Indicators

\begin{tabular}{ll}
\hline Indicator & Achievement \\
\hline 1. Be cooperative with friends & $\begin{array}{l}\text { a. Want to play with friends } \\
\text { b. Want to share with friends }\end{array}$ \\
& $\begin{array}{l}\text { a. Help each other friends } \\
\text { b. Don't compare friends with each other }\end{array}$ \\
3. Expressing emotions & a. Happy when you get something \\
according to conditions & b. Enthusiastic when doing the desired activity. \\
4. Know manners / manners & a. Speak politely \\
5. Show empathy & b. Obey the rules of the game \\
& a. Comforting a sad friend \\
& b. Break up a fighting friend
\end{tabular}

Construct validity is done by providing validity questionnaires to the appropriate constructs (experts). The results of construct validity from two experts (an expert on collegiate material and child development psychology). Empirical validity is done by testing the instrument on respondents or students who are not included in the research sample. The validity and reliability analysis empirically proves that the socio-emotional 
instrument is categorized as valid or appropriate to be used as a socio-emotional measurement tool for children, especially on the five indicators, being cooperative, showing tolerance, expressing emotions according to conditions, knowing manners / manners, and show empathy.

The scoring on the observation sheet uses a Likert scale with four ranges, and the answer choices have been modified according to the criteria for assessing early-childhood development. The criteria for development in early childhood consist of four scoring criteria. (1) The criteria for children who have not developed are stated with a score of 1 (one). (2) The criteria for children who are starting to develop are stated with a score of 2 (two). (3) The criteria for children who are developing as expected are stated with score 3. And the criterion for developing children very well is stated with a score of 4 four). The maximum score that may be obtained by early childhood in this study is 40 , while the minimum score is only 10 . For this reason, the classification of socio-emotional development scores is based on the indicators of the observation sheet and level. The classification of these scores is presented in Table 3.

Table 3. Development Criteria Based on Average Score

\begin{tabular}{lll}
\hline Score By Item & Based on Total Score & Information \\
\hline $1,00-1,74$ & $10,00-17,50$ & Undeveloped \\
$1,75-2,49$ & $17.51-25,00$ & Start Growing \\
$2,50-3,24$ & $25,01-32,50$ & Developing as Expected \\
$3,25-4,00$ & $32,51-40,00$ & Very Well Developed \\
\hline
\end{tabular}

\subsection{Data Analysis}

The data obtained from the instrument were then analyzed using inferential statistics. Inferential statistics are used to prove research hypotheses and draw inferences or conclusions from the results of hypothesis testing. The inferential statistical formula used in this study is the t-test. This is because the t-test is used to test the comparative hypothesis if the two data are interval type, normally distributed, and classified as parametric. The hypotheses proven in this study, (1) there is no difference in the effect between the edutainment learning model and the group on the socio-emotional development of early childhood $\left(\mathrm{H}_{0}\right)$. There is a difference in the effect between edutainment and group learning models on the socio-emotional development of early childhood $\left(\mathrm{H}_{\mathrm{a}}\right)$.

Regarding the results of proving the hypothesis are made based on the comparison of the $t_{\text {count }}$ and $t_{\text {table }}$ scores at a significance level of $5 \%$ or an alpha coefficient of 0.05 . If the calculation of the t-test formula obtains a tcount score that is greater than the table score, the conclusion is that the alternative hypothesis is accepted $\left(h_{a}\right)$ and the null hypothesis is rejected $\left(h_{0}\right)$. And if the calculation formula t-test scores obtained $t_{\text {count }}$ smaller than table score then the conclusion accept the null hypothesis $\left(\mathrm{h}_{0}\right)$ and reject the alternative hypothesis $\left(h_{a}\right)$. 


\section{RESULT AND DISCUSSION}

\subsection{Result}

The implementation of learning in the experimental group applies the edutainment learning model, and in the control, group applies the group learning model. Initial observation (pre-test) was carried out before the teacher applied the learning model and the final observation (post-test) was carried out after the teacher applied the learning model. The Results of the pre-test and post-test are presented in Table 4. From the table it is obtained data that there is an increase in the score of socio-emotional development of early childhood after they apply the learning model in each class, but there are differences in scores in the experimental class and the control class. Socioemotional children in the two classes have increased scores. The average pre-test score in the experimental class was 24.30 (Starting to Develop) then increased to 38.70 (Very Good Development) in the post-test score. The Average pre-test score in the control class was 23.70 (Starting to Develop) then increased to 34.80 (Very Good Development) in the post-test score.

Table 4. Total Score of Children's Socio-emotional Development

\begin{tabular}{lrrrr}
\hline No. & \multicolumn{2}{c}{ Experiment } & \multicolumn{2}{c}{ Control } \\
\hline & Pretest & Posttest & Pretest & Posttest \\
\hline 1 & 20,00 & 37,00 & 20,00 & 30,00 \\
2 & 20,00 & 37,00 & 20,00 & 30,00 \\
3 & 23,00 & 38,00 & 20,00 & 35,00 \\
4 & 23,00 & 38,00 & 20,00 & 35,00 \\
5 & 23,00 & 39,00 & 23,00 & 35,00 \\
6 & 23,00 & 39,00 & 23,00 & 36,00 \\
7 & 23,00 & 39,00 & 27,00 & 36,00 \\
8 & 27,00 & 40,00 & 28,00 & 37,00 \\
9 & 27,00 & 40,00 & 28,00 & 37,00 \\
10 & 28,00 & 40,00 & 28,00 & 37,00 \\
\hline Total & 243,00 & 387,00 & 237,00 & 348,00 \\
\hline Mean Score & 24,30 & 38,70 & 23,70 & 34,80 \\
\hline
\end{tabular}

The average social-emotional score obtained by children on each achievement indicator has increased from the pre-test stage to the post-test stage as shown in Table 5. Judging from the average pre-test score in the experimental class, the child got the lowest score (2.00) in the experimental class indicators of five highest the highest score (3.10) on the achievement of indicators of wanting to play with friends (1a). The score increased in the post-test, so that the child lowest the lowest score (3.60) on the two achievement indicators highest the highest score (4.00) on the six achievement indicators. While in the control class, children lowest the lowest score (2.00) on five achievement indicators highest the highest score (3.00) on two achievement indicators, willing to play with friends (1a) and willing to share with friends (1b). This value also increased in the posttest, so that the lowest got the lowest score (3.20) on the five achievements highest and the highest score (3.80) on the four achievement indicators. 
Table 5. Average Score of Children's Socio-emotional Development Indicator Achievement in Experiment and Control Classes

\begin{tabular}{lllllllllllll}
\hline Group & Data & \multicolumn{1}{c}{ Average Score on Indicator } & \multicolumn{3}{c}{ Total } \\
& & $1 \mathrm{a}$ & $1 \mathrm{~b}$ & $2 \mathrm{a}$ & $2 \mathrm{~b}$ & $3 \mathrm{a}$ & $3 \mathrm{~b}$ & $4 \mathrm{a}$ & $4 \mathrm{~b}$ & $5 \mathrm{a}$ & $5 \mathrm{~b}$ & Score \\
\hline Experiment & Pretest & 3,10 & 3,00 & 2,80 & 2,60 & 2,00 & 2,00 & 2,00 & 2,00 & 2,80 & 2,00 & 24,30 \\
& Posttest & 4,00 & 4,00 & 3,80 & 3,60 & 4,00 & 4,00 & 4,00 & 4,00 & 3,70 & 3,60 & 38,70 \\
Control & Pretest & 3,00 & 3,00 & 2,60 & 2,40 & 2,00 & 2,00 & 2,00 & 2,00 & 2,70 & 2,00 & 23,70 \\
& Posttest & 3,80 & 3,80 & 3,60 & 3,20 & 3,20 & 3,20 & 3,80 & 3,80 & 3,20 & 3,20 & 34,80 \\
\hline
\end{tabular}

The increase in the average pre-test and post-test scores in the experimental and control groups cannot be used as evidence that there is a difference in the effect of the edutainment learning model and the group learning model. Thus, the test is continued to the hypothesis testing stage using the t-test formula. The t-test has a classical assumption test which includes normality and homogeneity. The results of the normality test are presented in Table 6 which shows that the pre-test data in the experimental group and the control group have a normal distribution or distribution of data. This is because the calculation of the normality of the pretest data obtained an $\mathrm{L}$ count score which is smaller than the $\mathrm{L}$ table score at a significance level of $5 \%$ or an alpha coefficient of 0.05 .

Table 6. The Result of Normality

\begin{tabular}{llll}
\hline \multirow{2}{*}{ Group } & \multicolumn{2}{l}{ Pre-test } & \\
\cline { 2 - 4 } & $\mathrm{L}_{\text {count }}$ & $\mathrm{L}_{\text {table }}$ & Explanation \\
\hline Experiment & 0,1807 & 0,258 & Normal \\
Control & 0,242 & 0,258 & Normal \\
\hline
\end{tabular}

Furthermore, the homogeneity test was carried out on the same data. The results of the homogeneity test are presented in Table 7 which shows that the pre-test data in both groups had homogeneous variances, as well as the post-test data. This is because the homogeneity calculation obtains an $\mathrm{F}$ count score (3.01) which is smaller than the $\mathrm{F}$ Table score (3.44) at a significance level of $5 \%$ or an alpha coefficient of 0.05 .

Table 7. The Result of Homogeneity

\begin{tabular}{lccl}
\hline Data & $\mathrm{F}_{\text {count }}$ & $\mathrm{F}_{\text {table }}$ & Explanation \\
\hline $\begin{array}{l}\text { Experiment } \\
\text { Control }\end{array}$ & 3,01 & 3,44 & Homogeneous \\
\hline
\end{tabular}

From the results of normality and homogeneity tests, it can be concluded that the data in this study obtained elements of classical assumptions for hypothesis testing using the t-test formula. This is because the data has been proven to be normal and homogeneous, so it can use parametric formulas. The results of the t-test are presented in Table 8. Hypothesis testing shows that there is a difference in the effect of edutainment and group learning models on the socio-emotional development of early childhood. Based on the comparison, the tcount score (5.9453) is greater than the table score (2.101) at a significance level of $5 \%$ or an alpha coefficient of 0.05 , so the results of the hypothesis calculation accept $h_{a}$ and reject $h_{0}$. 
Table 8. Hypothesis Testing Results

\begin{tabular}{lll}
\hline$t_{\text {count }}$ & table & Explanation \\
\hline 5,9453 & 2,101 & Accept $h_{a}$ and reject $h_{0}$ \\
\hline
\end{tabular}

\subsection{Discussion}

In this study, the edutainment learning model and group learning model were applied to children aged 5-6 years at RA ABATASA Yapuspenda Medan. The class that applies the edutainment learning model is declared as the experimental group, while the class that applies the group learning model is declared as the control group. The learning process in the experimental or control groups uses the same games that are already available at school. This was done so that the research intervention focused on the application of the learning model, not because of the influence of the media or game tools.

Research data shows that children in the experimental and control groups has the same level of socio-emotional development, starting to increase. After the edutainment learning and group learning were applied to each group of children, an increase in scores was obtained on the socio-emotional development of early childhood. It was analyzed based on the average post-test and post-test scores in each class. In the experimental class, the pretest mean score was 24.3 (starting to develop). The posttest mean score was 38.7 (very well developed). While in the control class, the average pretest score was 23.7 (starting to develop) and the post-test mean score of 34.8 (very well developed).

Several previous studies suggest that early childhood socio-emotional consists of conformity to social norms, commitment to group work, and tolerance of differences(Chiu \& Chow, 2011; Maitner et al., 2017; Mok, 2019). From Other studies, it can also be concluded that several indicators of socio-emotional development are used as a benchmark for children's socio-emotional scoring in this study. Socio-emotional development consists of five indicators, being cooperative with friends, showing tolerance, expressing emotions according to conditions, recognizing manners / manners, and showing empathy (Goldschmidt \& Pedro, 2019; Young et al., 2021).

From the analysis of the achievement score indicators also prove the same thing. Before the edutainment learning, model was applied to the experimental class, children obtained a pretest score in the range of 2.80 to 3.10 or had criteria for developing according to expectations on five achievement indicators, willing to play with friends, share with friends, helping friends, don't compare friends with each other, and comfort sad friends. While the other five achievement indicators obtained a pretest score of 2.00 or had criteria starting to develop, happy when getting something, enthusiastic when doing the activities they want, speaking politely, obeying the rules of the game, and adjusting friends who are fighting. After applying the edutainment learning model, children get scores in the range of 3.60 to 4.00 or have very well-developed criteria on all achievement indicators of socio-emotional development. 
This is in line with recent research, Nikolayev et al., (2021) show that there are 76 more types of edutainment-based digital games for preschoolers in the US, and they have a positive impact on children's learning. Edutainment has also been applied to the learning process in Malaysia and the research of Yusof et al., (2014) proves that edutainment learning can meet the learning needs of children with special needs. This is in line with the research of Dandashi et al., (2015) which proves that the implementation of edutainment in Qatar has a positive effect on the cognition, motivation, and emotions of children with special needs. Thus, edutainment has been applied in the learning process in various countries and has been shown to have a positive influence on children's potential, especially socio-emotional development.

In the control group, children scored in the range of 2.60 to 3.00 or had criteria for developing according to expectations on four achievement indicators, willing to play with friends, share with friends, helping each other, and comforting friends who were sad. While the other six achievement indicators obtained a pretest score in the range of 2.00 to 2.40 or had criteria starting to develop, not comparing friends with one another, happy when getting something, enthusiastic when doing the activities they want, speaking politely, obeying the rules of the game, and reconcile friends who fight. After applying the group learning model, children get scores in the range of 3.60 to 3.80 or have very well-developed criteria on five achievement indicators, willing to play with friends, share with friends, speaking politely, and obeying the rules of the game. While the other five achievement indicators obtained a posttest score of 3.20 or had the criteria for developing according to expectations on five indicator achievements, not comparing friends with one another, happy when getting something, enthusiastic when doing the activities they want, entertaining friends who are sad, and break up a fighting friend.

Sutherland et al., (2019) concluded that learning processing in groups was proven to be able to facilitate children's personal and social development. Through group learning, children will recognize how to work well together, develop understanding among group members, and create a sense of sharing. Thus, the group model is not a new learning model for early childhood education, and various researchers have proven that the group learning model has a positive impact on student learning outcomes. Research Cheng and Ray (2016) student-centered learning will affect the socio-emotional assets of early childhood. Application of the group learning model can affect student learning outcomes. The group learning model has also been applied in the learning process in various countries and has been shown to have a positive influence on the potential of children, especially socio-emotional development.

If analyzed from the achievement of indicators in each group, both the edutainment learning model and the group have an influence on the socio-emotional development of early childhood. However, the difference between the two effects is not yet clear, so that the fulfillment of the information is carried out through hypothesis testing. From hypothesis testing, it was found that there were differences in the effect of edutainment and group learning models on the socio-emotional development. The increase 
experienced by children in socio-emotional development scores is the impact of implementing different learning models. This is in line with the opinion that knowledge is the result of interaction with the environment through conditioning the stimulus that causes a response. Environmental changes can affect children's thoughts, feelings, and behavior gradually. The results of Hamada and Tsubaki's (2021) research also show that children are taught to produce good feelings by experiencing, imagining, and seeing the future of family, friends, environment, schools, shops, and so on through creative edutainment. Positive emotions lead to a shift in knowledge, and a shift in knowledge leads to the value of emotional discourse.

In this study, a group learning model was applied to a comparison, and children in this group also used traditional games so that intervention only occurred in the application of different learning models. Hurlock's (2001) theory suggests that group learning through games can balance right and left-brain functions to balance intellectual and socioemotional aspects. Vygotski's (2012) theory believes that children's mental, language and social development are supported and enhanced by others through social interaction. Through group learning, children will interact with their friends and teachers. Learning grouping children can interact with each other, be it cooperation, mutual help, and others. The interaction is focused on one material or lesson theme that has been designed by the teacher and then discussed or resolved by the child together. In the group learning process, there is an educational interaction as well as social interaction. Empirical data from teacher interviews, daily life stories from mothers and children, and classroom observations shed light on how this classroom setting, in which children are placed in small, mixed-ability groups coordinated by one community volunteer, can benefit children, and promote their cognitive, social, and emotional development. The findings imply that this type of inclusive classroom organization may reach children from underserved communities while still offering high-quality ECEC (Aubert et al., 2017).

This study also found things that strongly support the process of socio-emotional development of early childhood. This is the use of game tools that act as a supporting factor for the application of edutainment and group learning models. The use of game tools has a positive effect on children's potential. The results of this study not only convey a real contribution to schools but also to the advancement of science and learning in the PAUD realm. The learning process in the PAUD realm has the aim of forming character, fostering stable emotional skills, fostering a sense of wanting to learn, and teachers paying attention to all aspects of development in children so that they have readiness to take the world of higher formal education. The achievement of PAUD goals cannot be separated from the role of teachers who are directly involved in the learning process and guidance of children in the classroom. It's difficult to provide edutainment for preschoolers. The design is constrained by two factors, such as the purpose of creating educational systems and the eventual users are very young children at the start of their development process. As a result, adapting the software engineering process to build acceptable systems that meet educational goals and can be utilized by preschoolers is required. The outcomes of 
an educational process are measured through assessment, and it is advised that information be evaluated in the same way that it was presented (Guran et al., 2020).

This research proves is highly expected teachers use learning models can influence and improve children's development from any aspect, without forgetting the characteristics of early childhood learning require play activities. So, it is natural that the results in this study favor the edutainment learning model that utilizes play activities, game tools, and a fun learning process for children. The edutainment learning model also applies the four pillars of education according to UNESCO, learning to know, learning to do, learning to be, and learning to live together. This is because in the edutainment learning model, the teacher ensures all children participate in play activities (learning to do) and guide them to understand every play activity carried out has elements of knowledge, and skills must be achieved (learning to know), so that children play with real application of the concept. In these play activities, children play a direct role (learning to be) in the sense that all children must actively play or participate in game groups activities so that children will get used to interacting socially with their friends (learning to live together) and have positive emotions. In the application of the edutainment learning model, children are also invited to be responsible and cultivate a culture of neatness by involving them to tidy up the game tools and maintain them properly, even though the game tools are not the child's personal property.

\subsection{Limitation}

In addition to the real contribution, this study found several limitations. Submission of research limitations is not so that the reader understands the lack of research, but so that it can be used as consideration and improvement material if the reader wants to apply the same learning model. The limitation of this research lies in the role of teachers who are less effective in carrying out learning, because the edutainment learning model is a new model in schools so researchers should conduct upgrading and guidance to teachers regarding the application of edutainment learning models. Another limitation is the current learning conditions which are still hit by the COVID-19 pandemic, so that the duration of children's learning is shortened, and their social interaction activities are also limited so as not to spread the Covid-19 virus. This limitation has a negative impact on the conduct of research that observes children's socio-emotional development. However, the limitations found in this study can still be overcome so that the results of the study prove the truth, that the edutainment learning model has a better effect than the group learning model.

\section{CONCLUSION}

The edutainment and group learning models have an influence on the children's socioemotional, the average child gets the criteria for developing very well. However, the edutainment learning model has a better effect than the group learning model, so it is highly recommended for ECE teachers to use the edutainment learning model in the process of children learning. The Implementation of edutainment and group learning 
models uses the help of game tools, because one of the functions of ECE is the play function for children. The use of game tools reflects that the teacher can manage the class carefully because the hallmark of ECE is playing and should not be omitted in the learning process. The existence of classroom management from the teacher is expected to have a positive effect on the potential of children through learning activities that have been designed. The Study found that edutainment and group learning models can have an influence on children's socio-emotional development because of the support from other things, such as the game tools provided an effective classroom management.

\section{REFERENCES}

Afrianti, N. (2018). Permainan Tradisional, Alternatif Media Pengembangan Kompetensi Sosial-Emosi Anak Usia Dini [Traditional Games, Alternative Media for Early Childhood Social-Emotional Competence Development]. Cakrawala Dini: Jurnal Pendidikan Anak Usia Dini, 5(1). https://doi.org/10.17509/cd.v5i1.10405

Alwaely, S. A., Yousif, N. B. A., \& Mikhaylov, A. (2021). Emotional development in preschoolers and socialization. Early Child Development and Care, 191(16), 2484-2493. https://doi.org/10.1080/03004430.2020.1717480

Andri Oza, \& Zaman, B. (2016). Edutainment dalam Mata Pelajaran Pendidikan Agama Islam. Mudarrisa: Jurnal Kajian Pendidikan Islam, 8(1). https://doi.org/10.18326/mdr.v8i1.117-144

Aubert, A., Molina, S., Schubert, T., \& Vidu, A. (2017). Learning and inclusivity via Interactive Groups in early childhood education and care in the Hope school, Spain. Learning, Culture and Social Interaction, 13, 90-103. https://doi.org/10.1016/j.lcsi.2017.03.002

Breaux, R. P., Harvey, E. A., \& Lugo-Candelas, C. I. (2016). The Role of Parent Psychopathology in Emotion Socialization. Journal of Abnormal Child Psychology, 44(4), 731-743. PubMed. https://doi.org/10.1007/s10802-015-00623

Capurso, M., \& Ragni, B. (2016). Bridge Over Troubled Water: Perspective Connections between Coping and Play in Children. Frontiers in Psychology, 7, 1953. https://doi.org/10.3389/fpsyg.2016.01953 
Cheng, Y.-J., \& Ray, D. C. (2016). Child-Centered Group Play Therapy: Impact on Social-Emotional Assets of Kindergarten Children. The Journal for Specialists in Group Work, 4l(3), 209-237. https://doi.org/10.1080/01933922.2016.1197350

Chilingaryan, K., \& Zvereva, E. (2020). Edutainment As a New Tool for Development. JAEDU- International E-Journal of Advances in Education, 16, 9.

Chiu, M. M., \& Chow, B. W. Y. (2011). Classroom Discipline Across Forty-One Countries: School, Economic, and Cultural Differences. Journal of CrossCultural Psychology, $42(3)$,

$516-533$. https://doi.org/10.1177/0022022110381115

Chung, K. K. H., Lam, C. B., \& Liew, J. (2020). Studying Children's Social-Emotional Development in School and at Home through a Cultural Lens. Early Education and $\quad$ Development, $\quad 31(6), \quad 927-929$. https://doi.org/10.1080/10409289.2020.1782860

Crescenzi-Lanna, L., \& Grané-Oró, M. (2016). An Analysis of the Interaction Design of the Best Educational Apps for Children Aged Zero to Eight = Análisis del diseño interactivo de las mejores apps educativas para niños de ceroa ocho años.

Creswell, J. W. (2015). Educational research: Planning, conducting, and evaluating quantitative and qualitative research (Fifth edition). Pearson.

Dandashi, A., Karkar, A. G., Saad, S., Barhoumi, Z., Al-Jaam, J., \& El Saddik, A. (2015). Enhancing the Cognitive and Learning Skills of Children with Intellectual Disability through Physical Activity and Edutainment Games. International Journal of Distributed Sensor Networks, 11(6), 165165. https://doi.org/10.1155/2015/165165

Denham, S. A. (2006). Social-Emotional Competence as Support for School Readiness: What Is It and How Do We Assess It? Early Education and Development, 17(1), 57-89. https://doi.org/10.1207/s15566935eed1701_4

Eurenius, E., Richter Sundberg, L., Vaezghasemi, M., Silfverdal, S.-A., Ivarsson, A., \& Lindkvist, M. (2019). Social-emotional problems among three-year-olds differ 
based on the child's gender and custody arrangement. Acta Paediatrica (Oslo, Norway: 1992), 108(6), 1087-1095. PubMed. https://doi.org/10.1111/apa.14668

Goldschmidt, T., \& Pedro, A. (2019). Early childhood socio-emotional development indicators: Pre-school teachers' perceptions. Journal of Psychology in Africa, 29(5), 474-479. https://doi.org/10.1080/14330237.2019.1665887

Guran, A.-M., Cojocar, G. S., \& Dioşan, L. S. (2020). Developing smart edutainment for preschoolers: A multidisciplinary approach. Proceedings of the 2nd ACM SIGSOFT International Workshop on Education through Advanced Software Engineering and Artificial 20-26. https://doi.org/10.1145/3412453.3423197

Halle, T. G., \& Darling-Churchill, K. E. (2016). Review of measures of social and emotional development. Measuring Social and Emotional Development in Early Childhood, 45, 8-18. https://doi.org/10.1016/j.appdev.2016.02.003

Hamada, M., \& Tsubaki, M. (2021). Relationship Analysis between Children Interests and Their Positive Emotions for Mobile Libraries' Community Development in a Tsunami Area. Qualitative and Quantitative Methods in Libraries, 31.

Heller, S. S., Rice, J., Boothe, A., Sidell, M., Vaughn, K., Keyes, A., \& Nagle, G. (2012). Social-Emotional Development, School Readiness, Teacher-Child Interactions, and Classroom Environment. Early Education \& Development, 23(6), 919-944. https://doi.org/10.1080/10409289.2011.626387

Hirsh-Pasek, K., Zosh, J. M., Golinkoff, R. M., Gray, J. H., Robb, M. B., \& Kaufman, J. (2015). Putting Education in "Educational" Apps: Lessons from the Science of Learning. Psychological Science in the Public Interest, 16(1), 3-34. https://doi.org/10.1177/1529100615569721

Hurlock, E. B. (2001). Developmental Psychology. McGraw-Hill Education. https://books.google.co.id/books?id=DiovBU8zMA4C 
Maitner, A. T., Mackie, D. M., Pauketat, J. V. T., \& Smith, E. R. (2017). The Impact of Culture and Identity on Emotional Reactions to Insults. Journal of Cross-Cultural Psychology, 48(6), 892-913. https://doi.org/10.1177/0022022117701194

Marcelo, A. K., \& Yates, T. M. (2014). Prospective relations among pre-schoolers' play, coping, and adjustment as moderated by stressful events. Journal of Applied Developmental Psychology, $35(3)$

$223-233$. https://doi.org/10.1016/j.appdev.2014.01.001

McClelland, M. M., \& Cameron, C. E. (2011). Self-regulation and academic achievement in elementary school children. New Directions for Child and Adolescent Development, 2011(133), 29-44. https://doi.org/10.1002/cd.302

Mohd Yusof, A., Daniel, E. G. S., Low, W. Y., \& Ab. Aziz, K. (2014). Teachers' perception of mobile edutainment for special needs learners: The Malaysian case. International Journal of Inclusive Education, 18(12), 1237-1246. https://doi.org/10.1080/13603116.2014.885595

Mok, M. M. C. (2019). Social and emotional learning. Educational Psychology, 39(9), 1115-1118. https://doi.org/10.1080/01443410.2019.1654195

Munirah. (2018). Urgensi Pengembangan Sosial dan Emosional Anak Usia Dini. Irfani, 14(1), 19-27.

Nasser, I., Miller-Idriss, C., \& Alwani, A. (2019). Reconceptualizing Education Transformation in Muslim Societies: The Human Development Approach. The Journal of Education in Muslim Societies, 1(1), 3-25. JSTOR.

Nikolayev, M., Reich, S. M., Muskat, T., Tadjbakhsh, N., \& Callaghan, M. N. (2021). Review of feedback in edutainment games for preschoolers in the USA. Journal of Children and Media, 15(3), 358-375. https://doi.org/10.1080/17482798.2020.1815227

Nurmalitasari, F. (2015). Perkembangan Sosial Emosi Pada Anak Usia Prasekolah. Psikologi UGM, 23(2). https://doi.org/10.22146/bpsi.10567

Okan, Z. (2003). Edutainment: Is learning at risk? Br. J. Educ. Technol., 34, 255-264. 
Pojani, D., \& Rocco, R. (2020). Edutainment: Role-Playing versus Serious Gaming in Planning Education. Journal of Planning Education and Research, 0739456X2090225. https://doi.org/10.1177/0739456X20902251

Protassova, E. (2021). Emotional development in the educational preschool programs of Soviet and Post-Soviet Times. Russian Journal of Communication, 13(1), 97-109. https://doi.org/10.1080/19409419.2021.1884338

Purwanto, S. (2019). Unsur Pembelajaran Edutainment dalam Quantum Learning. AlFikri: Jurnal Studi Dan Penelitian Pendidikan Islam, 2(2). https://doi.org/10.30659/jspi.v2i2.5149

Ren, L., Knoche, L. L., \& Edwards, C. P. (2016). The Relation between Chinese Preschoolers' Social-Emotional Competence and Preacademic Skills. Early Education and Development, 27(7), 875-895. https://doi.org/10.1080/10409289.2016.1151719

Rose-Krasnor, L. (1997). The Nature of Social Competence: A Theoretical Review. Social Development, 6, 111-135.

Rusydi, N. A. (2018). Pengaruh Penerapan Metode Edutainment Dalam Pembelajaran Terhadap Hasil Belajar IPS Murid SD Kartika XX-1. Dikdas Matappa: Jurnal Ilmu Pendidikan Dasar, 1(2). https://doi.org/10.31100/dikdas.v1i2.281

Shodiqin, R. (2016). Pembelajaran Berbasis Edutainment [Edutainment-Based Learning]. Jurnal Al-Maqayis, 4(1). https://doi.org/doi:http://dx.doi.org/10.18592/jams.v4i1.792

Sprung, M., Münch, H. M., Harris, P. L., Ebesutani, C., \& Hofmann, S. G. (2015). Children's emotion understanding: A meta-analysis of training studies. Developmental Review, 37, 41-65. https://doi.org/10.1016/j.dr.2015.05.001

Sutherland, S., Stuhr, P. T., Ressler, J., Smith, C., \& Wiggin, A. (2019). A Model for Group Processing in Cooperative Learning. Journal of Physical Education, Recreation \& Dance, $\quad 90(3), \quad 22-26$. https://doi.org/10.1080/07303084.2019.1559676 
Vygotski, L. S. (2012). Thought and Language. MIT Press.

Watanabe, N., Denham, S. A., Jones, N. M., Kobayashi, T., Bassett, H. H., \& Ferrier, D. E. (2019). Working Toward Cross-Cultural Adaptation: Preliminary Psychometric Evaluation of the Affect Knowledge Test in Japanese Pre-schoolers. $\begin{array}{lll}\text { SAGE } \quad \text { Open, } & 9(2), & 2158244019846688 .\end{array}$ https://doi.org/10.1177/2158244019846688

Young, E. L., Moulton, S. E., \& Julian, A. (2021). Integrating social-emotionalbehavioural screening with early warning indicators in a high school setting. Preventing School Failure: Alternative Education for Children and Youth, 65(3), 255-265. https://doi.org/10.1080/1045988X.2021.1898319 